\title{
Analysis of Mustahik Empowerment Program in Indonesia: The Case of Non-State Zakat Organization
}

\author{
Mawardi $^{1 *}$, Budi Trianto ${ }^{2}$, Masrizal $^{3}$ \\ *) Corresponding email: mawardi@uin-suska.ac.id
}

Article History

Received: October $11^{\text {th }}, 2021$

Revised: November 25th 2021

December $11^{\text {th }}, 2021$

December $20^{\text {th }}, 2021$

Accepted: January $9^{\text {th }}, 2022$

\begin{abstract}
The mustahik (the poor and the needy) empowerment program is one of the priority activities carried out by the zakat institution. This study aims to determine whether organizational support and entrepreneurial characteristics possessed by mustahik affect the success of the mustahik empowerment program. This study also aims to determine whether the mustahik empowerment program can alleviate poverty. This research was conducted utilizing Partial Least Square-Structural Equation Modelling (PLS-SEM) method. The population in this study was the mustahiks who received empowerment programs from non-governmental zakat organizations in Pekanbaru City, with a total sample of 60 mustahiks. The results of this study found that there was a positive and significant relationship between organizational support and the mustahik empowerment program. This study also uncovered a significant positive relationship between entrepreneurial characteristics and the mustahik empowerment program. It was also unveiled that the mustahik empowerment program had a positive and significant relationship with the success of poverty alleviation. These results imply that organizational support and entrepreneurial characteristics are important variables in the mustahik empowerment program. Therefore, zakat institutions must pay more attention to these variables to get maximum results in poverty alleviation.
\end{abstract}

Keywords: Organizational support; Mustahik empowerment program; Entrepreneurs characteristic; Poverty alleviation; Non-state zakat organization

JEL Classification: D64; I32; L31

Type of paper: Research Paper

@ IJIEF 2022 published by Universitas Muhammadiyah Yogyakarta, Indonesia

DOI:

Web:

https://doi.org/10.18196/ijief.v5i1.12900 https://journal.umy.ac.id/index.php/ijief/article/view/12900

\section{Citation:}

Mawardi., Trianto, B., \& Masrizal. (2022). Analysis of mustahik empowerment program in Indonesia: The case of non-state zakat organization. International Journal of Islamic Economics and Finance (IIIEF), 5(1), 107-128, DOI: https://doi.org/10.18196/ijief.v5i1.12900.

\footnotetext{
${ }^{1}$ Universitas Islam Negeri Sultan Syarif Kasim Riau, Indonesia

2 Sekolah Tinggi Ekonomi Islam Iqra Annisa, Indonesia

${ }^{3}$ Universitas Airlangga, Indonesia
} 
Mawardi, Trianto, \& Masrizal | Analysis of Mustahik Empowerment Program in Indonesia: The Case of Non-State Zakat Organization

\section{Introduction}

\subsection{Background}

Broadly speaking, the problems faced by Muslim countries are chronic absolute poverty, high unemployment, inequality in income distribution, low levels of primary sector productivity, increased inequality in living standards, less than optimal fulfillment of public facilities (education and health), and worsening balance of payment sheets; also, the worst case is foreign affairs and the weakening of the institutional structure and a system of values and customs that have faded due to external influences (Affandi \& Astuti, 2014).

Shaikh (2017) also noted that most poverty occurs in Africa and Asia, and most Muslim-majority countries are on these continents. Half of the poverty accounts for a quarter of the total global population. In their study in Pakistan, Naveed \& Ali (2012) concluded that 58.7 million people lived in multidimensional poverty, with $46 \%$ of the rural population and $18 \%$ of the urban population. Furthermore, Raimi et al. (2014) identified double-digit poverty rates in nine predominantly Muslim countries, including Pakistan (24\%), Afghanistan (53\%), Indonesia (18\%), Iran (18\%), Bangladesh (45\%), Sudan (40\%), Yaman (45\%), Aljazair (23\%), Mesir (20\%), and Nigeria (70\%). The total number of people suffering from poverty in these countries is over 335 million. The causes of poverty in these countries are linked to ineffective government policies leading to increased income inequality and unfulfilled citizen expectations.

Affandi \& Astuti (2014), in their paper, stated that the poverty rate gap that occurs between Muslim-majority countries and Muslim minorities is very reasonable because the majority of Muslim countries are former colonies of Western colonial countries. During the colonial period, human resources were underestimated, resulting in a sluggish national economy. Specifically, Indonesia is the largest Muslim country globally, and poverty is a major issue that is always being discussed from year to year. Poverty seems to be a scourge that has always haunted the government. Why not? Many people live below the poverty line in a country rich in natural resources, as described in Table 1.

The community has not optimally felt all the government's programs. Various efforts and policies have been made to reduce poverty. For this reason, as the largest community state, it is fitting to create a policy of its own to get out of poverty. 
Mawardi, Trianto, \& Masrizal | Analysis of Mustahik Empowerment Program in Indonesia: The Case of Non-State Zakat Organization

Table 1. Number of Poor People in Indonesia

\begin{tabular}{cccc}
\hline \multirow{2}{*}{ No } & Yea $r$ & \multicolumn{2}{c}{ Number of Poor Population (people) } \\
\cline { 3 - 4 } & & City & Village \\
\hline 1 & 2010 & 232989.00 & 192354.00 \\
2 & 2011 & 263594.00 & 223181.00 \\
3 & 2012 & 277382.00 & 240441.00 \\
4 & 2013 & 326853.00 & 296681.00 \\
5 & 2014 & 308826.00 & 275779.00 \\
6 & 2015 & 356378.00 & 333034.00 \\
7 & 2016 & 372114.00 & 350420.00 \\
8 & 2017 & 425770.00 & 392154.00 \\
9 & 2018 & 400995.00 & 370910.00 \\
10 & 2019 & 458380.00 & 418515.00 \\
11 & 2020 & 475477.00 & 437902.00 \\
\hline
\end{tabular}

Source: Central Bureau of Statistics (BPS), 2020

From an Islamic perspective (Al-Qur'an and Sunnah), poverty should be eliminated from society. Therefore, Islam hates and prohibits begging but encourages entrepreneurship (Abdul-Majeed Alaro \& Alalubosa, 2018). However, there is a condition where a person is at such a disadvantage that he cannot make ends meet. In fact, Islam has established a social support mechanism to overcome the problem of poverty, namely by encouraging every Muslim to help his brother who needs it.

Islam has many institutions capable of overcoming poverty in society. One such instrument is the zakat. Azam et al., (2014) stated that zakat significantly improves household welfare and alleviates poverty. As an instrument of poverty alleviation, zakat is currently collected by the governments of several Muslim countries. Libya, Malaysia (different sultanates), Pakistan, Saudi Arabia, Sudan, and Yemen collect zakat through government initiatives. Although Bahrain, Bangladesh, Egypt, Iran, Iraq, Jordan, Kuwait, Qatar, Indonesia, and Oman have established special public institutions, the payment of zakat to government agencies in these countries is voluntary. As the largest Muslim population, Indonesia certainly has great potential in zakat. A study conducted by Puskas Baznas in 2019 showed that the potential for zakat in Indonesia 2019 reached 233.8 trillion (IDR). In this case, the income zakat indicator became the sector with the highest zakat value of 139.07 trillion (IDR), then in the form of money of 58.76 trillion (IDR), agricultural zakat of 19.79 trillion (IDR) and farm zakat of 9.51 trillion (IDR). According to data from the Islamic financial report (2014: 35), the estimated potential for collecting zakat in Indonesia contributed to a GDP of $3.89 \%$ or 217 trillion (IDR).

Moreover, the poverty level in Indonesia is almost evenly distributed in every province, but the severity of poverty in each province is different. Different 
Mawardi, Trianto, \& Masrizal | Analysis of Mustahik Empowerment Program in Indonesia: The Case of Non-State Zakat Organization

levels of poverty in each province are caused by many things, such as the rate of economic growth, the rate of inflation, openness to investment, and others. Riau Province, for example, has 12 districts/cities with the center of government being Pekanbaru city, which is the largest city in Riau Province and is a trade and service city, including cities with high growth, migration, and urbanization, and the largest Muslim population of $85.94 \%$ (BPS). In this regard, one of the patterns used to alleviate poverty is to empower the duafa (the poor). The empowerment program can be carried out to help the duafa to be able to pursue their own life properly and independently. Qardhawi (2015) explained that the role of zakat is not only limited to poverty alleviation. However, empowering zakat can solve other problems. In overcoming these community problems, zakat management can be carried out in a productive direction by empowering people entitled to receive zakat.

In Pekanbaru, the poor community empowerment program mostly uses this concept. In empowering the poor, two patterns are used, namely group empowerment and individual empowerment. The group empowerment model is where the coaching is carried out in groups, and the business carried out is also a group business or joint venture. Meanwhile, the individual empowerment model is where the coaching is carried out jointly, but they run their respective businesses. To make the program successful, zakat institutions provide technical and non-technical support. Technical support provides business capital, training or courses, mentoring teams, and business equipment. On the other hand, the non-technical assistance provided is in the form of motivation and entrepreneurship training. Technical support aims to make running a business easier for mustahik (the poor and the needy), while non-technical support intends to strengthen and give enthusiasm in doing business.

In carrying out the mustahik empowerment program through micro-business development, of course, zakat institutions experience various obstacles. The obstacle faced during the empowerment program implementation is the lack of assistants to assist and evaluate the planned program; as a result, the mustahik walk alone without maximum assistance. Some zakat organizations, such as Swadaya Ummah and Dompet Duafa, explained that they did not have the human resource to monitor and evaluate the program intensively. The employees of the zakat organization were also limited, so they had difficulty in running the program even though mentoring, in this case, is vital in every empowerment program. The problem of assistant personnel is also inseparable from the budget provided, where the budget for economic programs is not too much so that its use must also be as efficient as possible. Consequently, the amount of business capital assistance for mustahik was relatively small, and the operational costs for the mentoring team were also limited. 
Mawardi, Trianto, \& Masrizal | Analysis of Mustahik Empowerment Program in Indonesia: The Case of Non-State Zakat Organization

Apart from the above problems, another problem related to mustahik empowerment in the economic field is the mustahik's endurance in running a business. Mustahiks sometimes have difficulty marketing their business results, which makes them frustrated, affecting the mustahiks' endurance in running a business. As a result, their business is not what they want. The endurance of these mustahiks is, of course, related to entrepreneurial characteristics. Entrepreneurial characteristics are an attitude that an entrepreneur must have so that in any condition, he will always survive and innovate to find solutions to the problems faced so that the business carried out will be successful ( Nair \& Pandey, 2006; Lumpkin \& Dess, 1996).

Some researchers have been interested in studying mustahik empowerment programs, such as Taufiq et al., (2018), Furqani et al., (2018), Nurzaman (2016), Trianto et al., (2020), Muhamat et al. (2013), and Lessy (2013). However, there is still a space that previous researchers have not studied, for example, examining the theory of organizational support developed by Rhoades \& Eisenberger(2002) and the theory of entrepreneurial characteristics put forward by Dingee et al. (1997) in the mustahik empowerment program, especially in non-governmental zakat organizations in Pekanbaru. This research was conducted to fill this gap, and it is important to do this research to see the contribution of the zakat institution's organizational support in empowering mustahik. The results of this study are expected to help the zakat institution evaluate the mustahik empowerment program, both evaluating the form of assistance provided and assessing the mustahik selection. The results of this study can also be used as a consideration for the government in alleviating poverty.

\subsection{Objectives}

Therefore, the purpose of this study is to determine whether the support provided by zakat institutions to mustahik and entrepreneurial characteristics influences the success of empowerment programs in the economic sector and how the impact on poverty alleviation of the mustahik. For this reason, the structure of this paper consists of five parts. The first part discusses the background of the research, covering the phenomenon of the mustahik empowerment program and the research gap. The second part reviews organizational support theory, mustahik empowerment theory, and poverty alleviation theory. The third section explains the analytical techniques utilized in this study. The fourth section discusses the study results, and the fifth section presents the study conclusions and recommendations. 
Mawardi, Trianto, \& Masrizal | Analysis of Mustahik Empowerment Program in Indonesia: The Case of Non-State Zakat Organization

\section{Literature Review}

\subsection{Theoretical Framework and Hypothesis Development}

\subsubsection{Zakat and Poverty Alleviation}

Poverty is a complex phenomenon and includes various aspects of life, from economic, social, and even policy conditions. Many experts and academics have developed the poverty concept. According to the Islamic Development Bank, by referring to the International Labor Organization (ILO) definition, poverty is the limitation in contributing effectively to society. Furthermore, people in poverty lack food and clothing for their families and lack sufficient education and health insurance. Neither do they have land to produce food nor have jobs and access to loans. Poverty also means insecurity, incapacity, and being wasted in the community. In addition, poverty is also very vulnerable to violence, and it is not uncommon to live in precarious conditions with a lack of access to clean water and sanitation (Muljawan et al., 2016).

According to the United National Development Program (UNDP), poverty is measured using the education index, health index, and the standard of daily living. Several studies used the cost of basic necessities, food energy intake, and subjective evaluation to measure poverty. Researchers at the 10th African Economic Conference discussed new gaps in poverty measurement. They believe that measuring poverty based on national average income does not accurately reveal the distribution of wealth to eradicate the threat of poverty (Ahmed, Johari, Wahab. 2017).

Poverty also generally indicates a level of income below a certain poverty line. People are called poor if they have an average expenditure per capita per month below the poverty line. The higher the poverty line, the more the population is classified as poor. However, the poverty limit used by each country varies. It is due to differences in location and living standards.

In the case of Indonesia, the Central Bureau of Statistics (BPS) uses the poverty limit of the number of rupiahs spent per capita per month to meet the minimum needs for food and non-food. The standard 2,100 calories per day are used for the minimum dietary requirement. Meanwhile, spending on nonfood minimum needs includes expenses for housing, clothing, and various goods and services. In other words, BPS uses the basic needs approach as an inability to meet basic needs. The basic needs approach is one of the main approaches to measuring absolute poverty in developing countries. It attempts to determine the absolute minimum resources necessary for longterm well-being, usually in the form of consumer goods (Atkinson, 2003). 
Mawardi, Trianto, \& Masrizal | Analysis of Mustahik Empowerment Program in Indonesia: The Case of Non-State Zakat Organization

From the Islamic perspective, poverty includes two aspects, namely material aspects and non-material aspects. A person said to be poor in terms of the world (material) is not necessarily poor in the spiritual aspect (afterlife). Materially poor people cannot meet basic needs properly, such as food, housing, clothing, health, and educational facilities. Meanwhile, spiritually poor people are those who do not have the minimum spiritual wealth, such as religious knowledge (ukhrawi) and general (worldly) knowledge, which is required in republication and taqarrub to Allah SWT by prioritizing moral values (Madjid, 2011).

In this case, zakat is an instrument to overcome social problems in developing countries, especially poverty and income inequality problems. Mahuyudin and Abdullah (2011) saw zakat as a tool of the Islamic economic system to eradicate poverty among Muslims and fulfill the social welfare of Muslims. They argued that zakat receipt, especially the poor and needy, must achieve the minimum quality of life that they receive.

Beik (2010) emphasized that the basic purpose of zakat is to solve social problems, such as poverty, unemployment, natural disasters, forests, unfair income distribution, and others. Therefore, the zakat distribution system is a solution to the problem of poverty and assistance for poor people regardless of race, color, and ethnicity. Sadeq (2002), in his research, found that zakat institutions can help eradicate poverty, which brings untold suffering.

In addition, poverty will encourage someone to beg as Islam condemns it. Thus, the poverty problem is not expected to become a serious problem in Islamic economics. Likewise, there is a consensus among scholars that a higher priority for zakat is eradicating poverty. The same thing was also stated by Abdullah, Derus, and Malkawi (2015) that zakat is a very effective way to help poor people get rid of poverty so that the collection and disbursement of zakat must be made effective. The main objective of zakat is to achieve socio-economic justice. Concerning the economic dimension of zakat, it aims to achieve beneficial effects on several dimensions, such as aggregate consumption, saving and investment, the aggregate supply of labor and capital, poverty alleviation, and economic growth (Wahab \& Rahman, 2011).

\subsubsection{Organizational Support}

Organizational support is perceived as an effort made by the organization to improve the performance of its employees. According to Rhoades \& Eisenberger (2002), organizational support can be from policies, norms, culture, legal, moral, and financial. Organizational support is also a global belief by employees as a form of company appreciation for employee performance. Organizational support theory emphasizes three aspects. Firstly, based on acceptance norms, perceived organization support (POS) 
Mawardi, Trianto, \& Masrizal | Analysis of Mustahik Empowerment Program in Indonesia: The Case of Non-State Zakat Organization

must provide assurance and attention to organizational welfare to achieve organizational goals. Second, attention, approval, and respect connote fulfilling social-emotional needs, leading workers to join organizations and transform status into social identities. All three POS must reinforce employees' belief that reward and organizational recognition will improve their performance (Rhoades \& Eisenberger, 2002).

In the context of empowering the poor, organizational support can be in the form of financial and non-financial assistance. In financial terms, it can be providing funds to purchase various purposes and business capital. Providing assistance in the form of funds can be carried out by non-profit organizations such as zakat organizations and other NGOs concerned with social problems and the government. Support made by the government can be in the form of pro-poor policies.

Empirical studies have shown that organizational support had a significant impact on the success of a program, such as research conducted by Lee et al., (2010), where organizational support had a positive and significant impact on enterprise resources planning. The same thing was found by Afzali et al. (2014) that organizational support significantly affected empowerment. Moreover, organizational support will also provide comfort to employees in accordance with the company's wishes (Paillé et al., 2010).

Meanwhile, research conducted by Muhamat et al., (2013) uncovered that the success of Asnaf's business in Malaysia was influenced by capital and knowledge. Capital, in this case, is important in starting a new business (startup business); this is one of the biggest obstacles for the needy and poor in building their business (Hadisumarto \& B.Ismail, 2010). What is no less important in the findings is knowledge, where the knowledge of the asnaf related to the business they run is more important than the training they take part in (Ghosh et al., 2011). However, different findings were conveyed by Voegtlin \& Boehm (2013) that training has a relationship with empowerment. From the description above, the following research hypothesis could be formulated:

\section{$\mathrm{H1}=$ Organizational support provided to empowerment program participants positively affects empowerment programs for the poor in the economic field.}

\subsubsection{Entrepreneur Characteristics}

One of the empowerment principles is the ability to empower agents to develop an entrepreneurial spirit. It is crucial since it is related to independence in running a business. Moreover, this empowerment focuses on the economic field. The target of empowerment in the economic sector is 
Mawardi, Trianto, \& Masrizal | Analysis of Mustahik Empowerment Program in Indonesia: The Case of Non-State Zakat Organization

how clients can increase family income through business. Dowling \& Schmude, and Fritsch \& Muller said that entrepreneurship is essential in personal and economic development (Cubico et al., 2010). The same thing was expressed by Brannback and Carsrud (2015) that entrepreneurship is a significant factor in creating national wealth, not only creating individual wealth. Entrepreneurs themselves do not have a single definition because they are complex and interrelated with various phenomena. However, to give an idea of what entrepreneurship is, there are several definitions, including those presented by Brannback and Carsrud, that an entrepreneur is defined as someone who tries to exploit opportunities to create wealth in the economic field.

Meanwhile, the European Commission defines an entrepreneur as a mindset and process for creating and developing economic activities by combining decision making on risk, creativity, and/or innovation with management through new and existing organizations (Cubico et al., 2010). Besides, Drucker (1984) emphasized economic entrepreneurship associated with innovation, so entrepreneurship is defined as an opportunity sought and exploited to satisfy one's wants and needs. A simpler definition is conveyed by O'Brien et al. (2017) that an entrepreneur organizes and manages risk in running a business.

To become a successful entrepreneur, several characteristics must be possessed, including drive and energy level, self-confidence, setting challenging but realistic goals, long-term involvement, using money as a performance measure, persistent problem solving, taking a moderate risk, taking the initiative and seeking personal responsibility, and making good use of resources (Dingee et al., 1970). Meanwhile, Lumpkin \& Dess (1996) stated that the keys to an entrepreneur's success are autonomy, innovation, risktaking, proactiveness, and competitive aggressiveness. The same thing was stated by Tagraf and Akin (2009), where an entrepreneur today has characteristics in risk-taking, autonomy, control of his own, and success confidence despite each kind of ambiguity.

In a study, it is explained that the entrepreneurial spirit is a factor that makes a pretty good contribution in running his business, such as a study conducted by Ahmad (2010), which compared the courage to take risks of an entrepreneurial CEO with a company CEO, where the level of courage to take risks of an entrepreneurial CEO was better than that of a company CEO. This finding is supported by the findings of Sarwoko et al., (2013) that the characteristics of an entrepreneur influence the success of the business he is running as well as findings from Leutner et al. (2014) and Abdulwahab \& Aldamen (2015). Based on the description above, the development of the next hypothesis could be described as follows: 
Mawardi, Trianto, \& Masrizal | Analysis of Mustahik Empowerment Program in Indonesia: The Case of Non-State Zakat Organization

$$
\begin{aligned}
& H 2= \text { Entrepreneurial characteristics possessed by mustahik have a } \\
& \text { positive influence on the success of empowerment programs in } \\
& \text { the economic field. }
\end{aligned}
$$

\subsubsection{Mustahik Empowerment}

Empowerment is one of the efforts to alleviate poverty by giving efforts to less fortunate people to improve their standard of living. In the Big Indonesian Dictionary, there are several meanings of empowerment. First, empowerment is defined as the ability to do something or the ability to act. Second, empowerment also means strength or energy (which causes a move). Third, empowerment is reason or effort. In terms of empowerment, it can be interpreted as an effort to provide power to the weak (powerless) and reduce power (disempowered) to those who are too powerful so that there is a balance (Djohani, cited by Anwas, 2013). Empowerment can also be understood as to how people, organizations, and communities are directed to control or rule over their lives (Rappaport, 1984).

Meanwhile, World Bank (2002) defines that empowerment as an expansion of the assets and abilities of the poor to participate in, negotiate with, influence, control, and hold the responsibility of institutions that affect their lives. Poverty includes multidimensional life, and poor people need assets and abilities at the individual level, such as health, education, and housing and at the collectivity level in the form of the ability to organize and mobilize collectively to solve problems. Empowerment of the poor can be carried out by the government or community. Through PNPM Mandiri, the Indonesian government has empowered the poor by facilitating various activities, including mentoring, training, and direct grants. Besides being held by the government, the empowerment of the poor (mustahik) can also be carried out by zakat institutions through the mustahik empowerment program by way of economic activities.

The level of success of the empowerment program can be seen from several aspects. The first is the impact aspect. The impact aspect arising from empowerment is the indicator of increasing family income. At the business level, the indicator can be seen from the business's net income, while at the household and individual levels, there is a change in annual income. Second, it is seen from the outcome aspect, where the indicator can be seen from how much wages the community gets. Third, seen from the aspect of outputs, the indicator is how much community participation in empowerment, how many other parties use alumni training, and how many products are produced. The four aspects of the activity are the manager's commitment to the empowerment program (Merkel, 2014). 
Mawardi, Trianto, \& Masrizal | Analysis of Mustahik Empowerment Program in Indonesia: The Case of Non-State Zakat Organization

Further, the ultimate goal of empowerment is the creation of economic independence for the mustahik, which in turn has implications for their escape from poverty. Empirical studies have shown that economic empowerment could help overcome family financial problems, as in research conducted by Lessy (2013) that, in general, economic empowerment in collaboration with one BUMN as a provider of funds has succeeded in improving the family economy.

Other researchers have also revealed that empowering the poor through productive zakat has led low-income families to fulfill their basic needs on their own (Trianto, 2018). Nurzaman (2016) used the human development index (HDI) approach; one of the topics discussed was the income index. Even though the results were still below the average expectation, they have provided hope for a better life. Using a logistic regression approach, Azzam et al., (2014) found that household expenditure after receiving zakat allocation increased, meaning there was an economic impact resulting from zakat. Beik (2013), in his study, unveiled that the contribution of zakat funds in alleviating poverty was not as expected. From 1,195 samples, zakat funds could only increase family monthly income by $8.94 \%$. Even so, the existence of zakat has contributed to reducing poverty up to $16.79 \%$. Based on the explanation above, the research hypothesis could be formulated as follows:

$\mathrm{H} 3=$ Empowerment of the poor through economic activities has a positive effect in alleviating poverty for mustahik.

\section{Methodology}

\subsection{Data}

This research was conducted in Pekanbaru, where the samples involved in this study were mustahiks who received empowerment programs from three zakat institutions in Pekanbaru, namely Dompet Dhuafa Riau, Rumah Zakat Riau, and Swadaya Ummah Pekanbaru. The three zakat institutions were chosen because they had experience implementing mustahik empowerment programs in Pekanbaru. Non-probability sampling was applied with a total sample of 60 mustahik. Data were collected directly from mustahik using the Likert Scale 1 - 5. Table 1 described the distribution of samples based on zakat institutions.

Table 1. Distribution of Samples

\begin{tabular}{llcc}
\hline No & Zakat Organization & Total Sample & Percentage \\
\hline 1 & Dompet Duafa & 15 & 25.00 \\
2 & Rumah Zakat & 29 & 48.33 \\
3 & Swadaya Ummah & 16 & 26.67 \\
& Total & 60 & 100.00 \\
\hline
\end{tabular}


Mawardi, Trianto, \& Masrizal | Analysis of Mustahik Empowerment Program in Indonesia: The Case of Non-State Zakat Organization

\subsection{Model Development}

The variables involved in this study consisted of four latent variables: organizational support, entrepreneurial characteristics, mustahik empowerment programs, and poverty alleviation (see Figure 1). The organizational support variable used the Roadess and Eissenberger theory, with four manifest variables: capital support, technical support, mentoring, and training. Meanwhile, the entrepreneurial characteristics variable employed the concept offered by Dingee et al. (1997), where nine manifest variables were involved: drive and energy level, self-confidence, setting challenging but realistic goals, long-term involvement, using money as a performance measure, persistent problem solving, taking a moderate risk, taking the initiative and seeking personal responsibility, and making good use of resources. Then, the level of success of the empowerment program can be seen from several aspects (Merkel, 2014), namely the impact aspect, outcome aspect, and output aspect. Moreover, the poverty alleviation variable utilized the concept of M. Shabri Abdul Madjid with two manifest variables: financial and non-financial. Figure 1 is describe the empirical model.

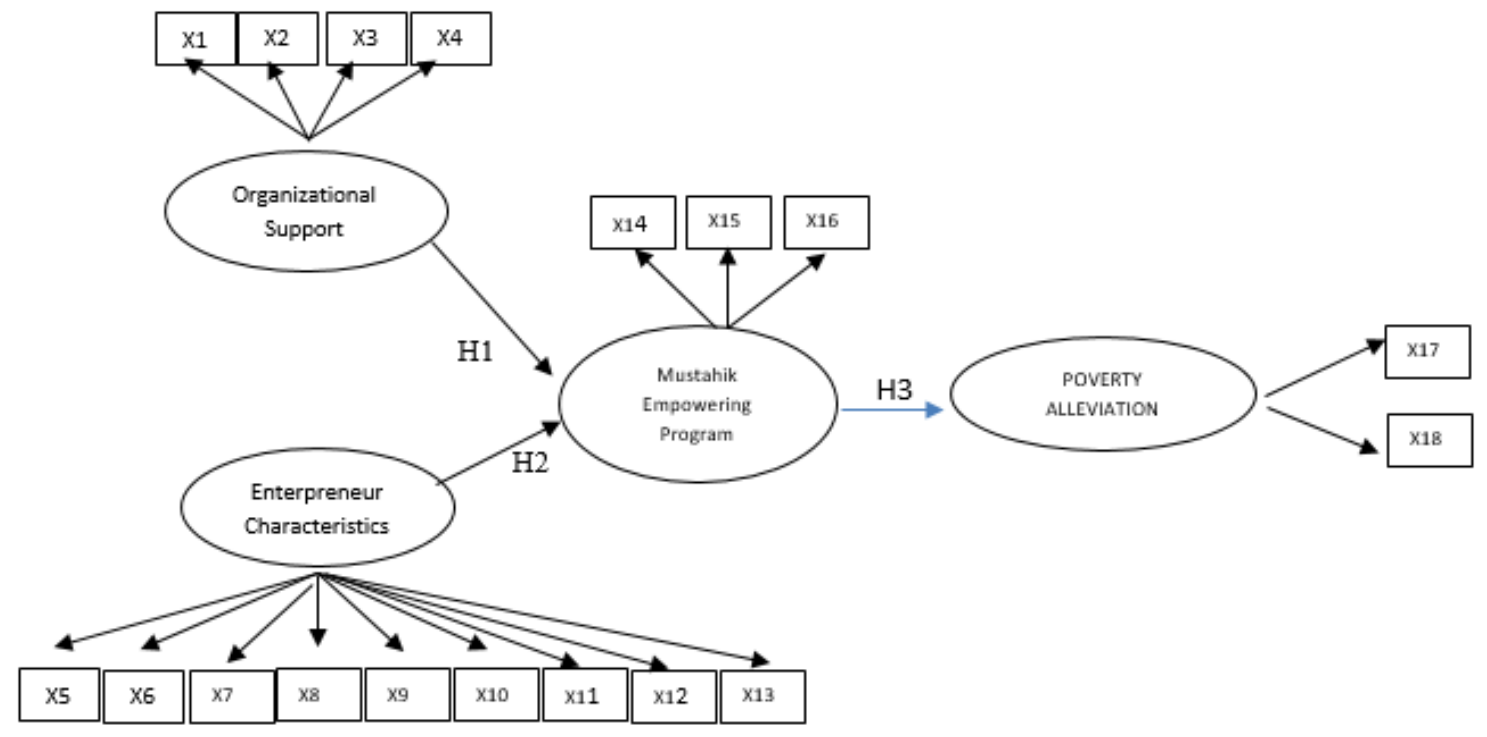

Figure 1. Empirical Model

\subsection{Method}

The structural equation model (SEM) method was used to test the model proposed in this study. SEM is a statistical methodology that takes a confirmatory approach to structural theory analysis related to several phenomena (Jamshidi \& Hussin, 2018). The statistical analysis follows structural equation modeling techniques to link measured observations with conceptual constructs (Majchrzak et al., 2005). Among the various SEM methods, the partial least squares (PLS)-SEM method has been chosen for 
Mawardi, Trianto, \& Masrizal | Analysis of Mustahik Empowerment Program in Indonesia: The Case of Non-State Zakat Organization

various reasons. First, the PLS-SEM method avoids the study's small sample size problems. Second, the PLS-SEM method provides a simultaneous evaluation of a model's structural and measurement components; in fact, this capability ensures that construct measures are reliable and valid before attempting to draw conclusions. Finally, PLS-SEM requires less stringent assumptions regarding the distribution of variables and error terms and ensures that multicollinearity problems are not a problem (Jamshidi \& Hussin, 2016). This analysis tool was chosen to analyze complex models (Hair et al., 2013). Therefore, the analysis in the study was carried out by the SmartPLS 3.0 software.

\section{Results and Analysis}

\subsection{Results}

\subsubsection{Mustahik Demographic}

The results of this study indicated that the empowerment program carried out by non-governmental zakat organizations was dominated by female mustahik who reached 50 people, as many as $83.33 \%$. Meanwhile, male mustahik only reached ten people or $16.67 \%$. It denotes that non-governmental zakat organizations prioritized female mustahik. Moreover, the education level of mustahik was mostly dominated by those with education up to a high school of 32 mustahik or reaching $53.33 \%$. On the other hand, the mustahik who had a low level of education (elementary and junior high school) reached 25 people or $41.67 \%$. In Table 2, it is also shown that Rumah Zakat had the greatest number of mustahik empowered, reaching 29 people or $48.33 \%$, followed by Swadaya Ummah at 26.67\% and Dompet Duafa at $25.00 \%$.

Table 2. Mustahik Demographic

\begin{tabular}{|c|c|c|c|}
\hline No & Description & Total & Percentage \\
\hline \multirow[t]{3}{*}{1} & Gender & & \\
\hline & Male & 10 & 16.67 \\
\hline & Female & 50 & 83.33 \\
\hline \multirow[t]{5}{*}{2} & Education & & \\
\hline & Elementary School & 6 & 10.00 \\
\hline & Junior High School & 19 & 31.67 \\
\hline & Senior High School & 32 & 53.33 \\
\hline & University & 3 & 05.00 \\
\hline \multirow[t]{5}{*}{3} & Age & & \\
\hline & $18-30$ years old & 3 & 05.00 \\
\hline & $30-40$ years old & 17 & 28.33 \\
\hline & $40-50$ years old & 31 & 51.67 \\
\hline & Above 50 years old & 9 & 15.00 \\
\hline
\end{tabular}


Mawardi, Trianto, \& Masrizal | Analysis of Mustahik Empowerment Program in Indonesia: The Case of Non-State Zakat Organization

\subsubsection{Measurement Model Evaluation}

The first step in conducting SEM-PLS analysis is to conduct a measurement model evaluation (shown in figure 2), consisting of loading estimate, average variance extracted (AVE), and composite reliability (CR). Hair et al. (2011) suggest that the recommended loading estimate value is $>0.50$; the AVE value is at least 0.5 and a CR of 0.7 . In this study, the researchers found that $X 1, X 6$, $X 7$, and $X 13$ were not valid because the loading factor values were below 0.5 . Therefore, the researchers removed them from the analysis. Table 3 displays that all loading estimate values were above 0.50 , meaning that all indicator variables used in the study truly reflected the variable construct. The values of AVE and CR were also above the provisions so that the data used was valid and reliable.

Table 3. Measurement Model Evaluation

\begin{tabular}{ccccc}
\hline Laten Variables & Items & Loading Estimate & AVE & CR \\
\hline Organizational Support & X2 & 0.859 & 0.746 & 0.898 \\
& X3 & 0.901 & & \\
& X4 & 0.830 & & \\
\hline Entrepreneurial Characteristic & X5 & 0.750 & 0.577 & 0.891 \\
& X8 & 0.855 & & \\
& X9 & 0.726 & & \\
& X10 & 0.780 & & \\
& X11 & 0.731 & & \\
& X12 & 0.706 & & \\
\hline Mustahik Empowerment & X14 & 0.856 & 0.672 & 0.859 \\
& X15 & 0.749 & & \\
X16 & 0.850 & & \\
\hline Poverty Alleviation & X17 & 0.928 & 0.621 & 0.759 \\
& X18 & 0.617 & & \\
\hline
\end{tabular}

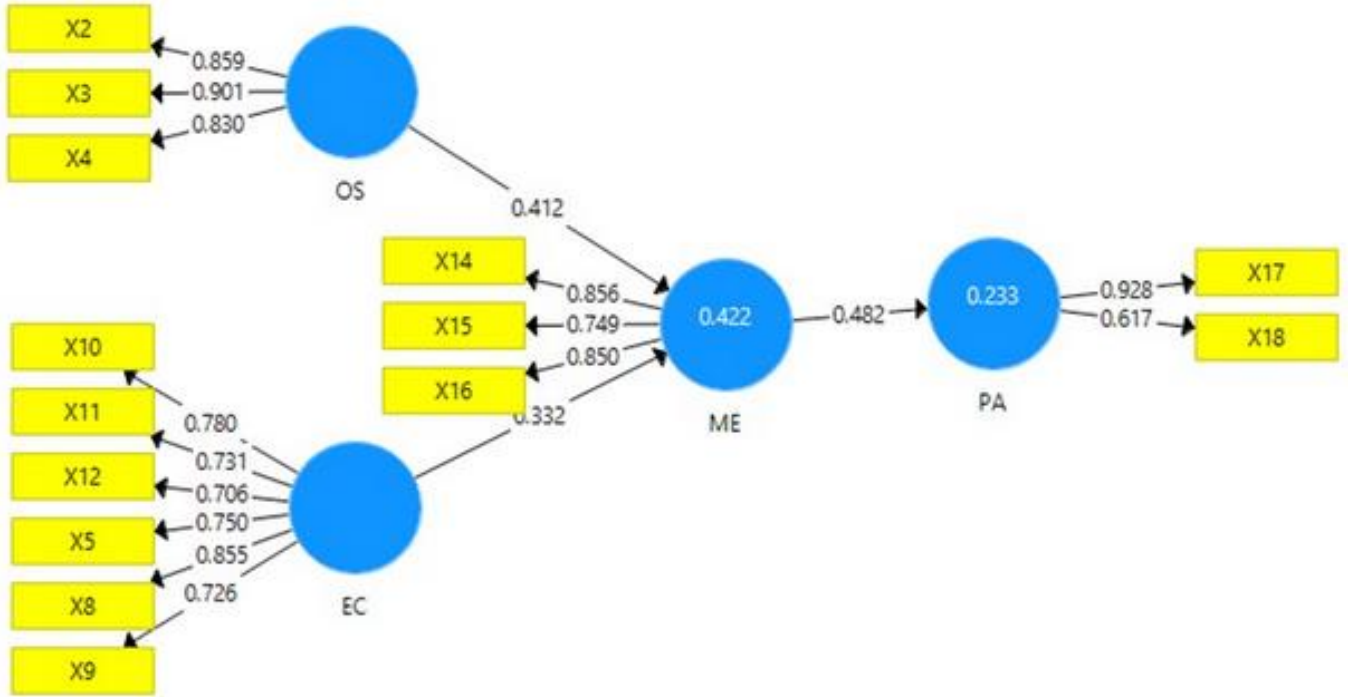

Figure 2. Measurement Model 
Mawardi, Trianto, \& Masrizal | Analysis of Mustahik Empowerment Program in Indonesia: The Case of Non-State Zakat Organization

\subsubsection{Structural Model Evaluation}

The structural model evaluation model is the last step in the SEM analysis. This stage is to see the relationship between exogenous and endogenous variables. The results of this study indicated that the success of the mustahik empowerment program carried out by non-governmental zakat institutions was influenced by organizational support. The influence could be shown from the resulting coefficient value of 0.412 , with a $p$-value of 0.006 . Therefore, the hypothesis proposed in this study could be accepted or supported as H1. It shown in table 4.

Meanwhile, mustahik's entrepreneurial characteristics had a positive and significant effect. It could be seen from the p-value of 0.035, with the estimated path coefficient of 0.332 . Therefore, the hypothesis proposed $(\mathrm{H} 2)$ in this study was accepted. Another result in this study is that the empowerment program carried out by non-governmental zakat organizations could alleviate poverty, with a magnitude of influence of 0.482 . For this reason, the hypothesis proposed in this study could be accepted ( $\mathrm{H} 3$ was accepted).

Table 4. Inner Model Evaluation

\begin{tabular}{lcccc}
\hline \multicolumn{1}{c}{ Relationship } & Estimate & t-statistics & P-value & Remarks \\
\hline $\begin{array}{l}\text { ORGANIZATIONAL SUPPORT->MUSTAHIK } \\
\text { EMPOWERMENT }\end{array}$ & 0.412 & 2.778 & $0.006^{*}$ & Supported \\
ENTREPENEUR CHARACTERISTIC->MUSTAHIK & 0.332 & 2.109 & $0.035^{*}$ & Supported \\
EMPOWERMENT & & & & \\
MUSTAHIK EMPOWERMENT->POVERTY & 0.482 & 4.357 & $0.000^{*}$ & Supported \\
ALLEVIATION & & &
\end{tabular}

\subsection{Analysis}

The mustahik empowerment program carried out by the zakat institution aims to alleviate poverty. The results of this study indicated that the support provided by the zakat institution in the form of capital assistance, mentoring, and training had a positive and significant effect. The results of this study are consistent with research conducted by Lee et al. (2010), Afzali et al. (2014), and Paillé et al. (2010). In research conducted by Lee et al. (2010), the support provided by the company to employees had a good impact on doing work. Likewise, in a study carried out by Afzali et al. (2014), the support provided by the company to employees had an impact on employee performance. Even though this research was conducted on non-profit-oriented organizations, the results were the same; namely, organizational support could make a real contribution to the empowerment of mustahik. It signifies that the organizational support theory developed by Rhoades \& Eisenberger (2002) 
Mawardi, Trianto, \& Masrizal | Analysis of Mustahik Empowerment Program in Indonesia: The Case of Non-State Zakat Organization

can also be applied to non-profit organizations such as zakat. Paillé et al. (2010) argued that organizational support would also provide a sense of comfort to employees in accordance with the company's wishes. In the context of mustahik empowerment, the support provided by the zakat institution to mustahik provided a sense of comfort. They got attention from zakat institutions in various forms, and of course, this motivated mustahik to run this empowerment program seriously. This empirical fact found provides the direction that the mustahik empowerment program through microbusiness activities is a program that must be maintained and developed more broadly by the zakat institution. Zakat institutions also need to pay attention and increase the support provided to mustahik, especially in terms of assistance, training, and technical support, such as business equipment assistance.

Entrepreneurial characteristics possessed by mustahik also had a positive impact and were significant on the success of the empowerment program. The results of this study are in line with Sarwoko et al., (2013), Leutner et al. (2014), Abdulwahab \& Al-damen (2015), and Trianto et al. (2020). For this reason, serious consideration is needed from zakat management organizations that have empowerment programs to pay attention to the problem of mustahik characteristics in carrying out empowerment programs. Meanwhile, the mustahik empowerment program carried out by nongovernment zakat institutions has succeeded in eradicating poverty. The results of this study corroborate with research conducted by Trianto et al. (2018) and Taufiq et al., (2018). This result implies that non-governmental zakat institutions can play a crucial role in helping alleviate poverty. Therefore, the government must provide maximum support to zakat institutions managed independently by the community, both technical and regulatory supports.

\section{Conclusion and Recommendation}

\subsection{Conclusion}

The main objective of this study is to develop a theoretical model to predict and explain the success factors of mustahik empowerment in poverty reduction using the concept of organizational support and mustahik characteristics. The results of this study showed that organizational support had an essential role in empowering mustahik. Therefore, organizational support in the form of capital assistance, mentoring, training, and technical support must be a serious concern for zakat institutions. The more intense the support provided, the greater the mustahik's chance to succeed. In addition to organizational support, the entrepreneurial characteristics possessed by 
Mawardi, Trianto, \& Masrizal | Analysis of Mustahik Empowerment Program in Indonesia: The Case of Non-State Zakat Organization

mustahik made a major contribution to the mustahik empowerment program in this study. Mustahiks with entrepreneurial characteristics, such as longterm involvement, taking a moderate risk, or taking the initiative, will give them a strong mentality in running their business. A strong mentality in doing business will certainly impact the sustainability and success of the business. The success of this mustahik empowerment program then has implications for poverty alleviation. Those who successfully run their business will certainly impact increasing income. This increase in income will impact increasing their welfare and, in turn, will push them out of poverty.

However, this study has some limitations. First, this study only used mustahik from non-government zakat institutions in Pekanbaru, and it is possible that the results only applied to poverty alleviation in Pekanbaru. Second, the researchers only involved three non-governmental zakat institutions, and third, a small sample was used.

\subsection{Recommendation}

This study provides several important recommendations for zakat institution practitioners, regulators, and further research. For zakat institutions, the researchers recommend that the mustahik empowerment program get top priority since it can provide multiple impacts for mustahik, especially in improving welfare and poverty alleviation. One of the impacts from this program is mustahik getting income from their business. If the business is successfully developed even larger, it will be able to hire new employees. Thus, it will increase the income and welfare of the mustahik family. They also have the opportunity to get out of the poverty line. Therefore, this empowerment program is important to be developed and made a priority program by the zakat institution. In this case, zakat institutions can provide a larger portion of capital assistance, more intensive business assistance, and expansion of mustahik empowerment programs. We recommend zakat institutions to pay attention for criteria of mustahik who want to be given assistance such as passion in entrepreneurship, entrepreneurial experience and family work culture. This is done to minimize the risk of failure in running a business.

For regulators, the researchers recommend providing convenience for people who want to establish a zakat institution. The increase in zakat institutions managed by the community will increase the opportunities for alleviating poverty. The government also needs to encourage the government-owned zakat institution, namely BAZNAS, to synergize and collaborate in managing mustahik empowerment programs with non-government zakat institutions. The government can also provide assistance in the form of facilities for the development of micro-enterprises carried out by mustahik such as additional business capital (Interest-free). Finally, the researchers recommend further 
Mawardi, Trianto, \& Masrizal | Analysis of Mustahik Empowerment Program in Indonesia: The Case of Non-State Zakat Organization

research to test organizational support theory on government zakat organizations and increase the number of samples. 
Mawardi, Trianto, \& Masrizal | Analysis of Mustahik Empowerment Program in Indonesia: The Case of Non-State Zakat Organization

\section{References}

Abdullah, N., Mat Derus, A. \& Al-Malkawi, H.-A.N. (2015). The effectiveness of zakat in alleviating poverty and inequalities: A measurement using a newly developed technique. Humanomics, 31(3), 314-329.

Abdulwahab, M. H., \& Al-damen, R. A. (2015). The impact of entrepreneurs ' characteristics on small business success at medical instruments supplies organizations in Jordan Amman Arab University Business Administration Department Amman Arab University. International Journal of Business and Social Science, 6(8), 164-175.

Affandi, A. \& Puji Astuti, D. (2013), Dynamic model of Ibn Khaldun theory on poverty: Empirical analysis on the poverty in majority and minority Muslim population after the financial crisis. Humanomics, 29(2), 136160.

Ahmad, H. M. (2010). Professional CEO in SMEs. International Journal of Business and Management, 5(9), 203-213.

Atkinson, A. (2003). Multidimensional deprivation: Contrasting social welfare and counting approaches. Journal of Economic Inequality, 1(1), 51-65.

Afzali, A., Motahari, A. A., \& Hatami-Shirkouhi, L. (2014). Investigating the influence of perceived organizational support, psychological empowerment and organizational learning on job performance: An empirical investigation. Tehnicki Vjesnik, 21(3), 623-629.

Azam, M., Iqbal, N., \& Tayyab, M. (2014). Zakat and economic development: Micro and macro level evidence from pakistan. Bulletin of Business and Economics, 3(2), 85-95.

Beik, I. S. (2013). Economic role of zakat in reducing poverty and income inequality: A case study in the Province of DKI Jakarta, Indonesia. German: LAP LAMBERT Academic Publishing.

Brannback, M \& Carsrud, A. (2015). Fundamentals for becoming a successful entrepreneur, from business idea to launch and management. Person Education.

Cubico, S., Bortolani, E., Favretto, G., \& Sartori, R. (2010). Describing the entrepreneurial profile: The entrepreneurial aptitude test (TAI). International Journal of Entrepreneurship and Small Business, 11(4), 424-435.

Dingee, A. L. M., Haslett, B., \& Smollen, L. E. (1970). Characteristics of a successful entrepreneurial management team. Journal of Business Management \& Social Sciences Research (JBM\&SSR), 10(4), 50-62.

Drucker, P. (1986). Innovation and entrepreneurship, practice and principles. London: Taylor \& Francis, Ltd. 
Mawardi, Trianto, \& Masrizal | Analysis of Mustahik Empowerment Program in Indonesia: The Case of Non-State Zakat Organization

Furqani, H., Mulyany, R., \& Yunus, F. (2018). Zakat for economic empowerment (analyzing the models, strategy and implications of zakat productive program in Baitul Mal Aceh and Baznas Indonesia). latishadia, 11(2), 391.

Ghosh, P., Joshi, J. P., Satyawadi, R., Mukherjee, U., \& Ranjan, R. (2011). Evaluating effectiveness of a training programme with trainee reaction. Industrial and Commercial Training, 43(4), 247-255.

Hadisumarto, W.,M.S., \& B. Ismail, A. G. (2010). Improving the effectiveness of Islamic micro-financing: Learning from BMT experience, Humanomics, Vol. 26(1), 65-75.

Hair, J.F., Ringle, C.M. \& Sarstedt, M. (2011). PLS-SEM: indeed a silver bullet. Journal of Marketing Theory and Practice, 19(2), 139-152.

Hair, J.F., Hult, G.T.M., Ringle, C.M. \& Sarstedt, M. (2013). A premier on partial least squares structural equation modeling (PLS-SEM). CA: Sage Publication.

Jamshidi, D., \& Hussin, N. (2016). Forecasting patronage factors of Islamic credit card as a new e-commerce banking service: An integration of TAM with perceived religiosity and trust. Journal of Islamic Marketing, 7(4), 378-404.

Jamshidi, D., \& Hussin, N. (2018). An integrated adoption model for Islamic credit card: PLS-SEM based approach. Journal of Islamic Accounting and Business Research, 9(3), 308-335.

Lee, D., Lee, S. M., Olson, D. L., \& Chung, S. H. (2010). The effect of organizational support on ERP implementation. Industrial Management and Data Systems, 110(2), 269-283.

Leutner, F., Ahmetoglu, G., Akhtar, R., \& Chamorro-Premuzic, T. (2014). The relationship between the entrepreneurial personality and the Big Five personality traits. Personality and Individual Differences, 63, 58-63.

Lumpkin, G.T, \& Dess, G.G. (1996). Clarifying the Entrepreneurial Orientation Construct and Linking It to Performance. The Academy of Management Review, 21(1), 135-172

Madjid, M.S.A. (2011). Mengentaskan kemiskinan dalam perspektif ekonomi syariah, EKBISI : Jurnal Ekonomi dan Bisnis Islam, VI(1) : $43-52$

Merkel, E. (2014). Measuring women's economic empowerment in private sector development, guidelines for practitioners. The Donor Committee for Enterprise Development (DCED).

Muhamat, A.A., Jaafar, N., Rosly, H.E., \& Manan, H.A. (2013). An Appraisal on the business success of entrepreneurial asnaf: An empirical study on the state zakat organization (the Selangor Zakat Board or Lembaga Zakat Selangor) in Malaysia, Journal of Financial Reporting and Accounting. 11(1), 51-63. 
Mawardi, Trianto, \& Masrizal | Analysis of Mustahik Empowerment Program in Indonesia: The Case of Non-State Zakat Organization

Muljawan, D., Sukmana, R., \& Yumanita, D. (2016). Wakaf pengaturan dan tata kelola yang efektif. Jakarta: Depertemen Ekonomi dan Keuangan Syariah-Bank Indonesia.

Nair, K. R. G., \& Pandey, A. (2006). Characteristics of Entrepreneurs: The Journal of Entrepreneurship, 15(1), 47-61.

Nurzaman, M. S. (2016). Evaluating the impact of productive based zakat in the perspective of human development index: A comparative analysis. Kyoto Bulletin of Islamic Area Studies, 9(29), 42-62.

O’Brien, J., Szczesniak, S., Prokop, C. \& Lowe, J. (2017). Entrepreneurial characteristic and skills of entrepreneurs. Chapter 13, p.349. http://thssbusiness.com/business-10/chapter-13.pdf. Access Date : April 22nd, 2017.

Paillé, P., Bourdeau, L., \& Galois, I. (2010). Support, trust, satisfaction, intent to leave and citizenship at organizational level: A social exchange approach. International Journal of Organizational Analysis, 18(1), 41-58.

Raimi, L., Patel, A., \& Adelopo, I. (2014). Corporate social responsibility, waqf system and zakat system as faith-based model for poverty reduction. World Journal of Entrepreneurship, Management and Sustainable Development, 10(3), 228-242.

Rappaport, J. (2014). Studies in empowerment: Introduction to the issue. Studies in Empowerment: Steps Toward Understanding and Action. London, England: Routledge.

Rhoades, L., \& Eisenberger, R. (2002). Perceived organizational support: A review of the literature. Journal of Applied Psychology, 87(4), 698714.

Sarwoko, E., Surachman., Armanu., \& Hadiwidjojo, D. (2013). entrepreneurial characteristics and competency as determinants of business performance in SMEs. IOSR Journal of Business and Management, 7(3), 31-38. DOI: https://doi.org/10.9790/487x-0733138

Shaikh, S. A. (2017). Poverty alleviation through financing microenterprises with equity finance. Journal of Islamic Accounting and Business Research, 8(1), 87-99.

Taufiq, I.F., Kusnendi., \& Nurasyiah, A. (2018). The effect of productive zakat, business experience, and mentoring on farmers' revenues (survey on Lumbung Desa program by sinergi foundation in Cibaeud village, Cigalontang district, Tasikmalaya regency). International Journal of Zakat, 3(3), 55-67.

Trianto, B., Nasution, Y., \& Siregar, S. (2018). Analysis of poverty alleviation and financial inclusion in the mustahik empowerment program In Pekanbaru. Jurnal Ekonomi \& Studi Pembangunan, 19(2), 167-177. 
Mawardi, Trianto, \& Masrizal | Analysis of Mustahik Empowerment Program in Indonesia: The Case of Non-State Zakat Organization

Trianto, B., Siregar, S., \& Nasution, M. Y. (2020). Does the mustahik demographic and socio-cultural affect to the successful of poverty alleviation? International Journal of Zakat, 5(1), 67-81.

Voegtlin, C., Boehm, S. A., \& Bruch, H. (2015). How to empower employees: Using training to enhance work units' collective empowerment. International Journal of Manpower, 36(3), 354-373.

Wahab, N.A. \& Rahim Abdul Rahman, A. (2011). A framework to analyse the efficiency and governance of zakat institutions. Journal of Islamic Accounting and Business Research, 2(1), 43-63. 